Kalamatika: Jurnal Pendidikan Matematika

\title{
ANAL YSIS OF MATHEMATICS PROBLEMS IN THE 2013 CURRICULUM AND CAMBRIDGE CURRICULUMMATHEMATICS TEXTBOOKS
}

\author{
Ratu Sarah Fauziah Iskandar ${ }^{1}$, Aji Raditya ${ }^{2}$, Trisna Roy Pradipta ${ }^{3}$ \\ ${ }^{1}$ Universitas Muhammadiyah Tangerang, Jln. Perintis Kemerdekaan I/33, Tangerang, Indonesia. \\ sarfauziah@gmail.com \\ ${ }^{2}$ Universitas Muhammadiyah Tangerang, Jln. Perintis Kemerdekaan I/33, Tangerang, Indonesia. \\ Aji.raditya12@gmail.com \\ ${ }^{3}$ Universitas Muhammadiyah Prof. DR. Hamka, Jln.Tanah Merdeka, Jakarta Timur, Indonesia. \\ troymath@uhamka.ac.id
}

\begin{abstract}
Several factors influence the success of learning; one of them is the quality of textbooks. Textbooks have a pivotal role in learning, namely, representing the teacher's explanation in front of the class. Curricula have continuously changed because they are far from the expectations. In Indonesia, many schools have implemented an international curriculum to improve school quality. One of the curricula used is the Cambridge curriculum. This study analyzed the types of problems in the Cambridge and 2013 curriculum mathematics textbooks, especially on quadratic equations. This research utilized a six-dimensional analysis method which consists of mathematical activities, complexity level, answer form, contextual features, response types, and mathematical features. Furthermore, the data collection technique was carried out by analyzing and describing the types of questions in the 2013 curriculum and the Cambridge curriculum mathematics textbooks. The analysis focused on the quadratic equation topic in the 2013 curriculum and the Cambridge curriculum mathematics textbooks. The results shows that there is no difference between the types of problems in the 2013 curriculum and the Cambridge curriculum mathematics textbooks for quadratic equation topics. The framework of this study could be a reference for further research and used by mathematics textbook writers to create more diverse types of questions.
\end{abstract}

\section{ARTICLE INFORMATION}

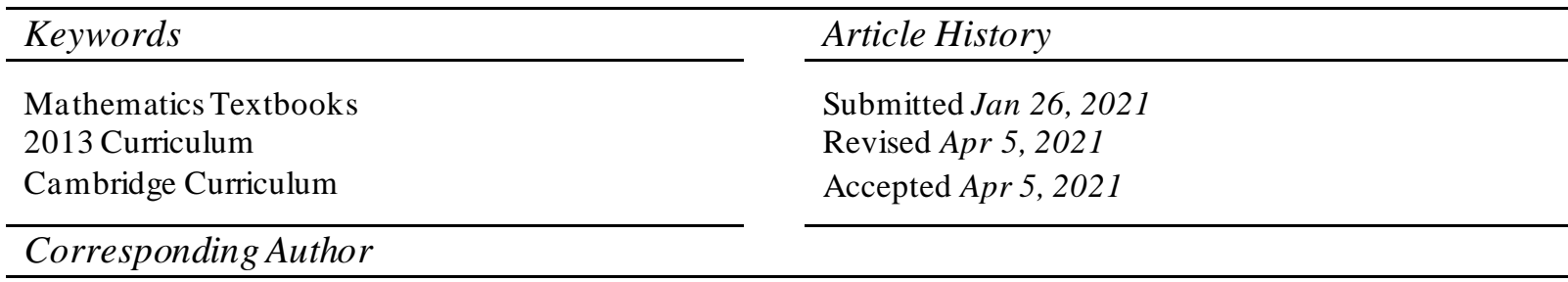

Trisna Roy Pradipta

Universitas Muhammadiyah Prof. DR. Hamka

Jln. Tanah Merdeka, Pasar Rebo, Jakarta Timur, Indonesia.

Email: troymath@uhamka.ac.id

\section{How to Cite}

Iskandar, R.S.F., Raditya,A., Pradipta,T.R. (2021). Analysis of Mathematics Problems in the 2013 Curriculu m and Cambridge Curriculum Mathematics Textbooks. Kalamatika: Jurnal Pendidikan Matematika, 6(1), 99-110.

https://doi.org/10.22236/KALAMATIKA.vol6no1.2021pp99-110 


\section{INTRODUCTION}

A system improvement could increase the quality of education. In Indonesia, remodeling textbooks to make them more appropriate and meet the applicable standards is one way to upgrade the education quality. Furthermore, Lessani, Yunus, Tarmiz, and Mahmud (2014) stated that students' knowledge and competence should be compared to other students from different countries to evaluate their performance and improve their achievement in science and mathematics at various levels of education. On the other hand, Mailizar, Alafaleq, \& Fan (2014) revealed that to improve the quality of student learning in any education system, the government has to pay attention to the curriculum.

The curriculum is the central part of the system and plays a pivotal role in determining how students learn and are taught in school. It is the most fundamental structure for educational experiences. It is a kind of underlying "skeleton" that gives characteristic shape and direction to instruction in educational systems worldwide (Houang \& Schmidt, 2008). The curriculum is defined as a statement, and students are expected to know and could do it (Levin, Connelly, \& Lundgren, 2008). Richards (2001) claimed that the curriculum includes educational planning based on several processes that result in the development, implementation, and evaluation of language development.

The curriculum is also essential in Indonesia, which adopts a centralized education system. Thus, the 2013 curriculum revised is a solution to improve the deficiency of the previous 2013 curriculum. Furthermore, the educational goals will never be achieved appropriately if the curriculum is not equipped with qualified textbooks (Pramesti, 2017). A textbook can have a prominent position and role in implementing a mathematics curriculum (Johansson, 2003). A textbook is organized intentionally, and consequently, its content and structure are essential for promoting a specific vision of a curriculum (Okeeffe, 2013). The textbook has been identified as one of the factors that influence students' learning outcomes. Sunday (2014) claimed that textbooks had been emphasized to be the most critical media in the mathematics teaching and learning process.

Textbook as teaching media is unique because it has specific characteristics. The textbook receives attention from the international research community on mathematics education during the last few decades (Lianghuo Fan, 2011). The mathematics textbook is the leading media on which the teachers lay their teaching (Gene, Zacharos, Lavidas, \& 
Koustourakis, 2018). It has been noted that the use of different mathematics textbooks by teachers leads to the adoption of different teaching strategies (L Fan \& Kaeley, 1998).

In mathematics, content-specific literacy skills of students are needed since there are particular properties of mathematical texts. The symbolic language is a property of mathematics that needs literacy skills (Österholm, 2006). In this regard, the quality of the problems in the textbook must be considered. Problems are often designed to reveal facts that students know (or do not know), as well as the techniques that students are good at (or not mastered) and how to use them in certain situations (Brändström, 2005). Lai (2011) claimed that books provide the core elements of the subject and have to develop students' critical and creative thinking.

Based on the use of textbooks as a source of information, they should in excellent quality and meet the criteria for the National Education Standards. However, mathematics textbook examples contain problem solutions and sometimes include reasoning with the different steps of the solution. Even though this reasoning might be founded on mathematical properties, it can be argued that the whole textbook examples are mostly presenting a rule or algorithm (Stacey \& Vincent, 2009).

While many researchers acknowledge the need for textbook analysis in mathematics education, a complete framework for textbook analysis remains unavailable. Most of the current textbook analysis research focused on the textbook's content, structure, and expectation (O'Keeffe \& O’Donoghue, 2015). Lessani et al. (2014) examined textbooks in Singapore which revealed that Singapore has a solid and well-developed curriculum that influences the syllabus of textbooks, mainly mathematics textbooks. There are various examples with more than the number of problems stated in the textbook in each subject. Therefore, throughout Singapore textbooks, the researcher claimed that the examples worked out reinforced the mathematical concepts through step-by-step guidance on both examples and solutions.

Other research focused on particular mathematics topics, for example, the concept of proportion (Dole \& Shield, 2008) and the concept of function (Mesa, 2004). Lianghuo Fan, Mailizar, Alafaleq, and Wang (2018) also presented a comparative analysis of textbook content, focusing on how geometric proofs are conveyed in secondary school mathematics textbooks in China, Indonesia, and Saudi Arabia. This comparative analysis considered three 
views: time to introduce evidence in the curriculum, distribution of evidence in textbooks, and the type of evidence introduced to students. Textbooks in China have the highest percentage of geometric content and pay the most attention to the topic of geometric proof itself.

Previous researchers have also conducted problem analysis of mathematics textbooks in Indonesia from the 1994 curriculum to the 2013 curriculum (2017 revision). Based on the study results, the questions in Indonesian textbooks generally have no significant changes even though the curriculum has changed from 1994 to 2017. The types of questions presented in mathematics textbooks in Indonesia still use various arithmetic operations, applying direct knowledge or basic skills without any daily life context. The existing questions are also the closed answer types; the questions only require direct answers without reason and a single procedure (Raditya, Iskandar, \& Suwarno, 2020). Furthermore, Purnomo (2015) stated that the 2013 curriculum mathematics textbook's questioning aspects are challenging to implement because students do not understand the questions and are not confident to answer. The questions in the teacher handbook are also too complicated, so the teacher has to look for other references. Thus, the current research was conducted to describe the comparison between problems provided in the 2013 curriculum mathematics textbooks in Indonesia and the Cambridge curriculum mathematics textbook, which is applied in more than 160 countries.

\section{METHOD}

This research is a descriptive analysis. The subjects in this study were quadratic equations topics in BSE mathematics textbooks of the 2013 curriculum (2014 revised edition) and Cambridge curriculum. This research method utilized the collection of problems, sample problems, and practice problems from the mathematics textbooks used. The framework in this study was a modification of the framework developed by Gracin (2018) and Li (2000), namely 6-dimensional analysis; mathematical activities, complexity level, answer form, contextual features, response types, and mathematical features for analyzing problems in mathematics textbooks in Indonesia. Then, the researcher classified and converted the problems in the mathematics textbook based on the framework into a coding system. The implemented framework is presented in Table 1. 
Table 1. Dimension and Sub-dimension

\begin{tabular}{ll}
\hline \multicolumn{1}{c}{ Dimension } & \multicolumn{1}{c}{ Sub-dimension } \\
\hline Mathematical Activity (A) & Representing or modeling (A1) \\
& Counting or presenting various counting operations (A2) \\
& Interpretation (A3) \\
& Providing an argument or logical reason (A4) \\
Problem complexity (B) & Application of direct knowledge or basic skills (B1) \\
& Making connections (B2) \\
& Applying reflectiveknowledge (B3) \\
& Closed Answers (C1) \\
Answer type (C) & Open Answers (C2) \\
& Multiple Choice Answers (C3) \\
Contextual situation (D) & Questions without context (D1) \\
& Problem with the context of fiction (D2) \\
Response type (E) & Questions with real-world contexts (D3) \\
& Answers only (no reason) (E1) \\
& Reason only (E2) \\
Mathematical Questions (F) & Answer using reason (E3) \\
& Single Procedure (F1) \\
& Layered Procedure (F2)
\end{tabular}

\section{RESULT AND DISCUSSION}

The study results indicated that, in general, there is no balance between the types of problems in Indonesian mathematics textbooks for the quadratic equation topic presented in the 2013 curriculum and Cambridge curriculum. Based on the dimensions of mathematical activity (dimension A), questions on the Cambridge curriculum textbook are mainly in the form of counting or presenting various counting operations (A2). In comparison, the mathematics textbooks of the 2013 curriculum are dominated by representing or modeling (A1) problems. In the dimension of problem complexity (dimension B), most of the problems in the 2013 curriculum mathematics textbook are in a phase of making connections (B2), while in the Cambridge curriculum, most of them are still in the form of application of direct knowledge or basic skills (B1). Furthermore, in the answers types (dimension C), both mathematics textbooks are still in the closed answer (C1) form. In the contextual situation dimension (dimension D), the type of question without context (D1) dominates the 2013 curriculum and Cambridge curriculum mathematics textbooks. In the dimension of response type (dimension E), short-answer (no reason) problems (E1) are dominant. Even in Cambridge curriculum mathematics textbooks, more than $90 \%$ of the problems are dominated by shortanswers problems. In the dimension of the mathematical problems (dimension F), the types of problems in the 2013 curriculum are mostly questioning types with layered procedures (F2), while the Cambridge curriculum mathematics textbooks are dominated mainly by single procedure (F1) type of problems. The comparison between the two mathematics textbooks could be seen in Table 2 . 
Table 2. Research Results

\begin{tabular}{|c|c|c|}
\hline \multirow[b]{2}{*}{ Sub-Dimensions and Codes } & \multicolumn{2}{|c|}{ Percentage } \\
\hline & 2013 Curriculum & $\begin{array}{l}\text { Cambridge } \\
\text { Curriculum }\end{array}$ \\
\hline Representing or modeling (A1) & $47.93 \%$ & $10.40 \%$ \\
\hline Counting or presenting various counting operations (A2) & $10.77 \%$ & $79.70 \%$ \\
\hline Interpretation (A3) & $32.31 \%$ & $9.90 \%$ \\
\hline Providing an argument or logical reason (A4) & $9.23 \%$ & $0.00 \%$ \\
\hline Application of direct knowledge or basic skills (B1) & $18.46 \%$ & $73.27 \%$ \\
\hline Making connections (B2) & $44.62 \%$ & $23.27 \%$ \\
\hline Applying reflective knowledge (B3) & $36.92 \%$ & $3.47 \%$ \\
\hline Closed Ans wers (C1) & $87.69 \%$ & $94.06 \%$ \\
\hline Open Answers (C2) & $12.31 \%$ & $0.00 \%$ \\
\hline Multiple Choice Ans wers (C3) & $0.00 \%$ & $5.94 \%$ \\
\hline Problems without context (D1) & $52.31 \%$ & $87.13 \%$ \\
\hline Problem with the context of fiction (D2) & $9.23 \%$ & $4.95 \%$ \\
\hline Problems with real-world contexts (D3) & $38.46 \%$ & $7.92 \%$ \\
\hline Answers only (no reason) (E1) & $58.46 \%$ & $94.06 \%$ \\
\hline Reason only (E2) & $16.92 \%$ & $0.00 \%$ \\
\hline Answer using reason (E3) & $24.62 \%$ & $5.94 \%$ \\
\hline Single Procedure (F1) & $26.15 \%$ & $87.13 \%$ \\
\hline Layered Procedure (F2) & $73.85 \%$ & $12.87 \%$ \\
\hline
\end{tabular}

Related to the dimension of mathematical activity (dimension A), the problems in the 2013 curriculum textbook with the highest percentage of $47.93 \%$ are the sub-dimensions of representing or modeling (A1), while $32.31 \%$ of interpretation (A3) sub-dimensions. On the other hand, the problems in the Cambridge curriculum textbooks are dominated by problems with counting or using various counting operations (A2) sub-dimensions which are $79.70 \%$. There is no problem in the Cambridge curriculum mathematics textbook related to providing an argument or logical reason (A4) sub-dimension. The comparison of dimension A could also be seen in Figure 1.

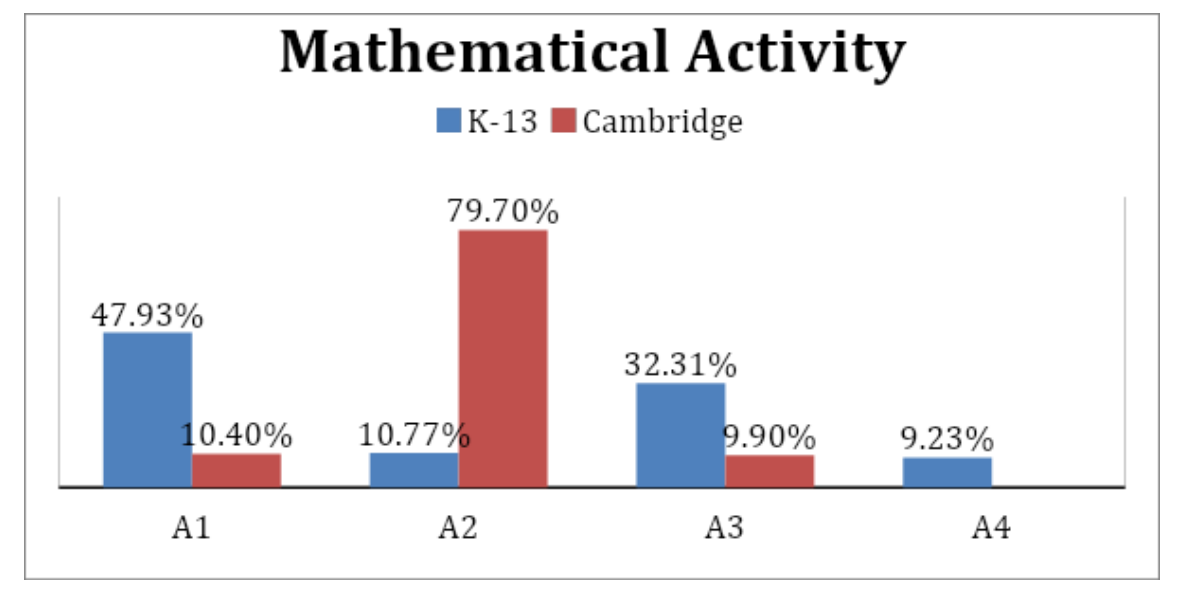

Figure 1. Diagram and Percentage of Mathematical Activity

In the problem complexity dimension (dimension B), the problems in the 2013 curriculum mathematics textbooks are dominated by making connections (B2) problems with a percentage of $44.62 \%$. This number is slightly different from applying reflective knowledge 
(B3), with a percentage of $36.92 \%$. The Cambridge curriculum is dominated by direct application of basic knowledge or skills (B1) problems with a percentage of $73.27 \%$. While in the same curriculum, the percentage of making connections (B2) and applying reflective knowledge (B3) problems are much lower than the application of direct knowledge or basic skills (B1). The comparison of dimension B could also be seen in Figure 2.

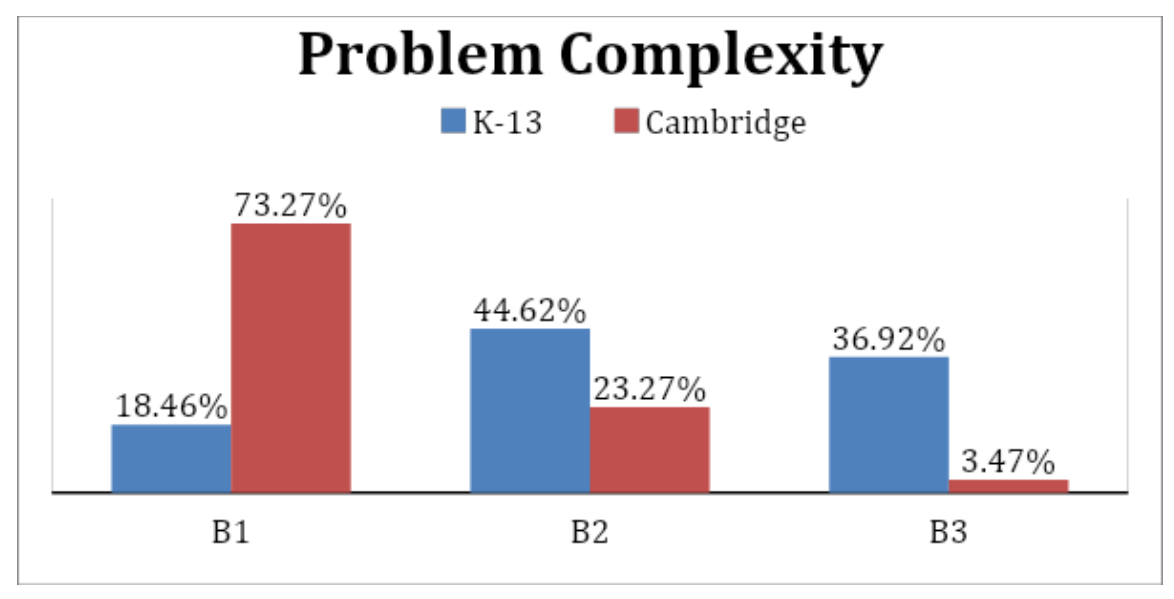

Figure 2. Diagram and Percentage of Problem Complexity

In the dimension of answer types (dimension $\mathrm{C}$ ), both curricula are dominated by closed answers $(\mathrm{C} 1)$ problems with a percentage of more than $85 \%$. The open answers $(\mathrm{C} 2)$ problems in the 2013 curriculum mathematics textbook are only $12.31 \%$, while there are no open answers in the Cambridge curriculum mathematics textbooks. Likewise, there is no problem with multiple choice answers (C3) on the 2013 curriculum, whereas it is less than 6\% of the $\mathrm{C} 3$ problems in the Cambridge curriculum. The comparison of dimension $\mathrm{C}$ could also be seen in Figure 3.

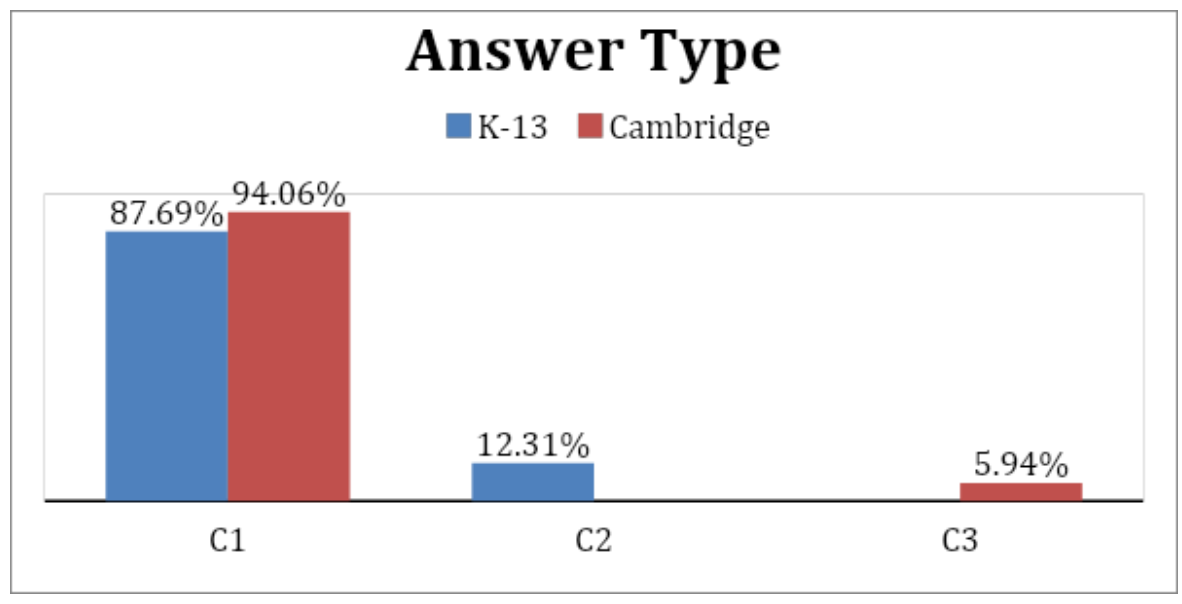

Figure 3. Diagram and Percentage of Answer Type 
The contextual situation (dimension D), without context problems (D1), dominates by $52.31 \%$ on the 2013 curriculum and $87.13 \%$ on the Cambridge curriculum. The percentage of problems with the context of fiction (D2) in both curricula is not more than $10 \%$. In the 2013 curriculum mathematics textbook, the real-world context (D3) problems reach 38.46\%, whereas the Cambridge curriculum mathematics textbook is only $7.92 \%$. The comparison of dimension D could also be seen in Figure 4.

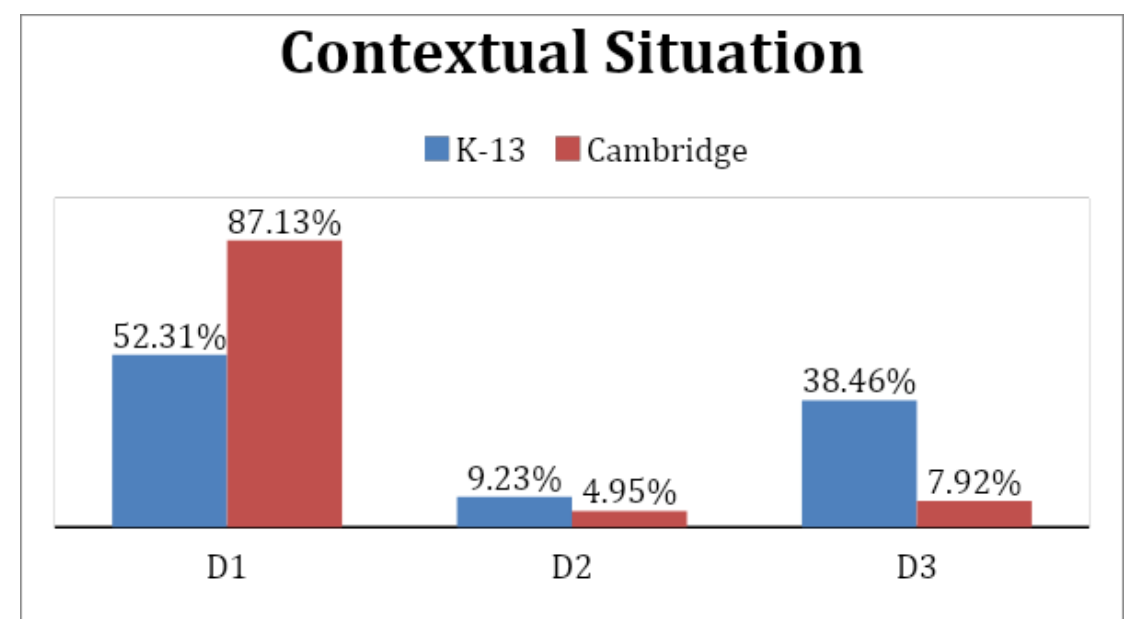

Figure 4. Diagram and Percentage of Contextual Situation

The answers only (no reason) (E1) problems in the response type dimension (dimension E) are still dominant in both curricula, namely $58.46 \%$ of the 2013 curriculum and $94.06 \%$ of the Cambridge curriculum. Reason-only (E2) problems are not presented in the Cambridge curriculum mathematics textbooks, while the 2013 curriculum reach 16.92\%. Furthermore, answer using reason (E3) problems are $5.94 \%$ of Cambridge curriculum mathematics textbook and $24.62 \%$ of the 2013 curriculum mathematics textbook. The comparison of dimension E could also be seen in Figure 5.

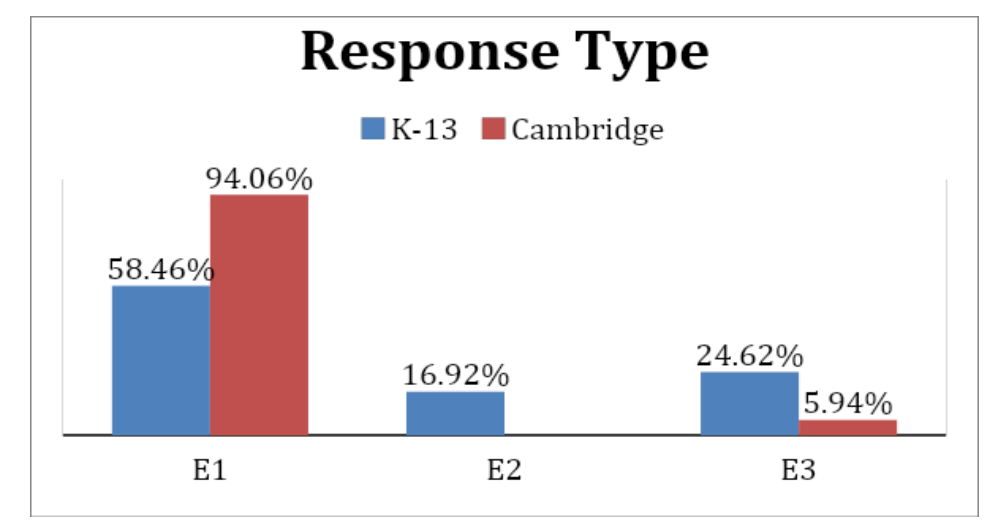

Figure 5. Diagram and Percentage of Response Type 
Mathematical problem dimension (dimension $\mathrm{F}$ ) with a single process (F1) problems in the Cambridge curriculum mathematics textbook has a higher percentage than layered process (F2) problems which equal 87.13\%. In contrast to the 2013 curriculum mathematics textbook, the layered process $(\mathrm{F} 2)$ problems are more significant than the single process $(\mathrm{F} 1), 73.85 \%$. The comparison of dimension F could also be seen in Figure 6.

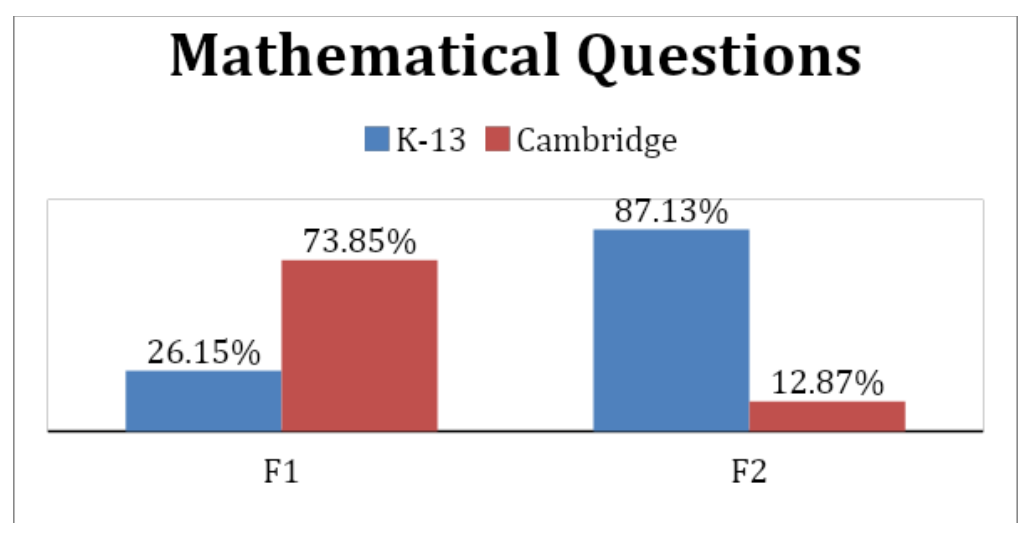

Figure 6. Diagram and Percentage of Mathematical problems

Based on the description, it can be seen that mathematics textbooks of the 2013 curriculum and the Cambridge curriculum have differences regarding mathematical activities. In 2013 curriculum textbooks, it is dominated by representing or modeling problems, while in the Cambridge curriculum textbooks, it is dominated by problems of counting or using various counting operations. Problems in the 2013 curriculum mathematics textbooks are dominated by making connections problems, whereas the Cambridge curriculum is dominated by applying reflective knowledge problems. Furthermore, the Cambridge curriculum mathematics textbook's single process problems have a higher percentage, which is inversely proportional to the 2013 curriculum mathematics textbook. Then, the percentage of layered process problems is more significant than the single process.

\section{CONCLUSION}

The 2013 curriculum applies a modern principle approach that refers to a scientific method in the Cambridge curriculum. The difference between the 2013 curriculum and the Cambridge curriculum is related to the learning system. The Cambridge curriculum is more focused on students' exciting subjects. Meanwhile, the national curriculum (one of them is the 2013 curriculum) equalizes all students' subjects. 
Based on the research results, it could be seen that in general, there is no balance between the 2013 curriculum and Cambridge curriculum mathematics textbooks type of problems in quadratic equation topic. The framework in this study could be a reference for further research and could be used by mathematics textbook writers to design more diverse types of problems.

\section{REFERENCES}

Brändström, A. (2005). Differentiated tasks in mathematics textbooks an analysis of the levels of difficulty. Dissertation, 1-97.

Fan, L, \& Kaeley, G. S. (1998). Textbook use and teaching strategies: An empirical study. The American Educational Research Association (AERA) Annual Meeting, v13, p2--9 STTextbook use and teaching strategies: Retrieved from http://ezproxy.acu.edu.au:2099/gw 1/ovidweb.cgi

Fan, Lianghuo. (2011). Textbook Research as Scientific Research: Towards a Common Ground for Research on Mathematics Textbooks, (October), 1-11.

Fan, Lianghuo, Mailizar, M., Alafaleq, M., \& Wang, Y. (2018). A Comparative Study on the Presentation of Geometric Proof in Secondary Mathematics Textbooks in China, Indonesia, and Saudi Arabia. In Lianghuo Fan, L. Trouche, C. Qi, S. Rezat, \& J. Visnovska (Eds.), Research on Mathematics Textbooks and Teachers' Resources: Advances and Issues (pp. 53-65). Cham: Springer International Publishing. https://doi.org/10.1007/978-3-319-73253-4_3

Gene, K., Zacharos, K., Lavidas, K., \& Koustourakis, G. (2018). An Analysis of School Mathematics Textbooks in Terms of Their Pedagogical Orientation. Open Journal for Educational Research, 2(1), 1-18. https://doi.org/10.32591/coas.ojer.0201.01001g

Gracin, D. G. (2018). Requirements in mathematics textbooks: a five-dimensional analysis of textbook exercises and examples. International Journal of Mathematical Education in Science and Technology, 49(7), 1003-1024. https://d oi.org/10.1080/0020739X.2018.1431849 
Houang, R. T., \& Schmidt, W. H. (2008). TIMSS International Curriculum Analysis and Measuring Educational Opportunities. 3rd IEA International Research Conference $\begin{array}{llll}\text { TIMSS, } & \text { Retrieved } & \text { from }\end{array}$ http://www.iea.nl/fileadmin/user_upload/IRC/IRC_2008/Papers/IRC2008_Houang_Sc hmidt.pdf

Johansson, M. (2003). Textbooks in mathematics education: A study of textbooks as the potentially implemented curriculum. Thesis.

Lai, Y. C. (2011). Designing Information and Communication Technology Textbooks for Senior Secondary Students: A Case Study in Hong Kong. The International Journal of the Book, 8(3), 33-50. https://doi.org/10.18848/1447-9516/CGP/v08i03/36891

Lessani, A., Yunus, A. S. M., Tarmiz, R. A., \& Mahmud, R. (2014). Why Singaporean 8th grade students gain highest mathematics ranking in TIMSS (1999-2011). International Education Studies, 7(11), 173-181. https://doi.org/10.5539/ies.v7n11p173

Levin, B., Connelly, G. A. M., \& Lundgren, U. P. (2008). Curriculum policy and the politics of what should be learned in schools. The SAGE Handbook of Curriculum and Instruction, 7-24. https://doi.org/10.4135/9781412976572.n1

Li, Y. (2000). A Comparison of Problems That Follow Selected Content Presentations in American and Chinese Mathematics Textbooks. Journal for Research in Mathematics Education, 31(2), 234-241. https://doi.org/10.2307/749754

Mailizar, M., Alafaleq, M., \& Fan, L. (2014). A historical overview of mathematics curriculum reform and development in modern Indonesia. Inovacije u Nastavi, 27(3), 58-68. https://doi.org/10.5937/inovacije1403058m

Mesa, V. (2004). Characterizing Practices Associated with Functions in Middle School Textbooks: An Empirical Approach. Educational Studies in Mathematics, 56(2), 255286. https://doi.org/10.1023/B:EDUC.0000040409.63571.56

O'Keeffe, L., \& O’Donoghue, J. (2015). a Role for Language Analysis in Mathematics Textbook Analysis. International Journal of Science and Mathematics Education, 
13(3), 605-630. https://doi.org/10.1007/s10763-013-9463-3

Okeeffe, L. (2013). A Framework for Textbook Analysis. International Review of Contemporary Learning Research, 2(1), 1-13. https://doi.org/10.12785/irclr/020101

Österholm, M. (2006). Characterizing Reading Comprehension of Mathematical Texts. Educational Studies in Mathematics, 63(3), 325-346. https://doi.org/10.1007/s10649005-9016-y

Pramesti, S. L. (2017). Analisis Materi Dan Penyajian Buku Teks Matematika Sebagai Sumber Belajar Matematika. Delta: Jurnal Ilmiah Pendidikan Matematika, 5(1), 25. https://doi.org/10.31941/delta.v5i1.386

Purnomo, moch. (2015). Integrasi Kurikulum Cambridge dalam Kurikulum 2013 pada Mata Pelajaran Matematika Sekolah Menengah Pertama (Perspektif Pengembangan Prosedur). Prosiding Seminar Nasional Matematika Dan Pendidikan Matematika UMS 2015, (ISBN : 978.602.361.002.0), 246-254.

Raditya, A., Iskandar, R., \& Suwarno, S. (2020). Questions Analysis in Mathematics Textbook from Competency-Based Curriculum up to Curriculum 2013, 3(2), 89-98. https://doi.org/10.24042/djm

Richards, J. C. (2001). Curriculum Development in Language Teaching. Curriculum Development in Language Teaching. https://doi.org/10.1017/cbo9780511667220

Samson Sunday, A. (2014). Mathematics Textbook Analysis: a Study on Recommended Mathematics Textbooks in School Use in Southwestern States of Nigeria. European Scientific Journal, 1(September), 1857-7881.

Stacey, K., \& Vincent, J. (2009). Modes of reasoning in explanations in Australian eighthgrade mathematics textbooks. Educational Studies in Mathematics, 72(3), 271-288. https://doi.org/10.1007/s10649-009-9193-1 